\section{CIVITAS Brings International Civic Educators to APSA}

Entering the fifth year of partnership in CIVITAS, an international collaboration for civic education, APSA hosted a number of briefing sessions for visiting educators from Eastern and Central Europe and Russia this year. Through this collaboration with CIVITAS, APSA is connecting political science scholars, scholarship, and teaching to education and democracy programs in countries around the world. CIVITAS participation offers APSA the opportunity to introduce precollege civic educators to our profession.

Between August 1999 and September 2000, APSA welcomed delegations from Poland, Russia, Latvia, Lithuania, and Bosnia. APSA staff presented information about the Association and civic education in the U.S. During the session, staff conducted a web demonstration and encouraged the delegations to keep in contact with APSA and political science scholars through electronic means. APSA provided publications and journals and complimentary APSA memberships to each delegation. Political scientists are encouraged to make direct contact with these educators.

Polish Delegation (March 20, 2000)

CIVITAS Poland Contact Jacek Strzemieczny, director, and Alicja Pacewicz, co-director, Center for Citizenship Education, ul. Willowa 9/3, 00-790 Warszawa, Poland; T/F: 48-22-849-85-13; ccejacek@ikp. atm.com.pl; www.civiced.org/civitas_ intl_poland.html

\section{Participants}

Grazyna Czetwertynska, university instructor, Institute of Classical Philology, Warsaw University, OBTA

Tomasz Merta, University Instructor, Department of Applied Social Sciences, Warsaw University

Malgorzata Osinska, teacher of history and teacher trainer
Danuta Sterna-Kaszubska, science teacher and teacher trainer Sharon Subreenduth, project coordinator, Civic Education Program, Mershon Center, Ohio State University

Russian Delegation (March 29, 2000) CIVITAS Russia Contact Pyotr Polozhevets, president, Russian Association for Civic Education (ACE), editor in chief, Uchitelskaya Gazeta, Vetoshny 13-15, 103012, Moscow, Russia; T/F: 7-095-928-8253; peterpol@redline.ru; www. civiced.org/civitas_intl_russia.html

Participants

Yuri Guk, teacher trainer and street law teacher

Olga Kravchenko, school principal Nikolai Obdirshikov, school principal and history and civics teacher

Nikolai Osipov, district social studies specialist

Yuri Shipakin, professor, Teacher Training Institute, and social studies specialist, Oblast Ministry

Tatyana Vereshagina, deputy principal and history, law, and civics teacher Evgeny Belyakov, director, Moscow Office, Civitas/AFT (Escort)

Shannon McLeod, program coordinator, AFT Educational Foundation (Escort) Sasha Nikolskaya, Translator (Escort)

\section{Latvian and Lithuanian Delegation (May 4, 2000)}

CIVITAS Latvia Contact Valts Sarma, president, and Dace Ulpe, coordinator for project, Citizen Activities in Latvia, Democracy Advancement Center, Bruninieku 29/31, Room 211, Riga, LV-1001, Latvia; T/F: 011-371-731-2147; Valts@apollo.lv; www.civiced.org/ civitas_intl_latvia.html

\section{CIVITAS Lithuania Contact} Giedre Kvieskiene, director, Lithuanian College of Democracy, Konarskio 18-59, LT-2009 Vilnius, Lithuania; T: 370-2-650-579; democ@ktl. mii.lt; www.ktl.mii.lt/
Participants

Mr. Valts Sarma, director, Democracy Advancement Center, Riga, Latvia Ms. Dace Ulpe, translator and librarian, Democracy and Advancement Center, Riga, Latvia

Ms. Giedre Kvieskiene, director, Lithuanian College of Democracy

Ms. Jurate Mazuyto, Study Circle Leader, Kaunas School of Light Industry and Business, Kaunas, Lithuania

Bosnian Delegation (November 1, 1999)

CIVITAS Bosnia and Herzegovina Contact

Rasema Dzinalija, Civitas@Bosnia and Herzegovina, c/o U.S. Embassy, Office of Public Affairs, Fra Andjela Zvizdovica I/X, UNIS Tower A, 71000 Sarajevo, Federation of Bosnia and Herzegovina; T: 011-387-71-665-851 or 921 ; F: 011-387-71-665-836; rdzinali@pd.state.gov; www. civiced.org/civitas_intl_bosnia.html

Participants

Ms. Zahida Sisic, literature professor and deputy minister of education, Zenica-Doboj Canton

Mr. Ismet Salihbegovic, deputy minister for education, Sarajevo Canton Mr. Esad Toromanovic, sociology professor, and CIVITAS cantonal coordinator for Una Sana Canton Mr. Karlo Zelenika, psychology and pedagogy professor, Siroki Brijeg, and CIVITAS cantonal coordinator Mr. Halil Spago, counselor for education, Mostar Canton Ministry of Education

Mr. Anton Milos, elementary school principal, and CIVITAS municipal coordinator for Kiseljak

Ms. Sanja Kantar, philosophy professor Mr. Dejan Krunic,

counselor for physics and astronomy, Pedagogical Institute of the Republika Srpska and CIVITAS regional coordinator

Mr. Mile Ilic, professor of pedagogy and psychology, University of Banja Luka Ms. Rahela Dzidic, executive director, CIVITAS in Bosnia and Herzegovina 